\title{
A Review of Temporary Housing Management Modeling: Trends in Design Strategies, Optimization Models, and Decision-Making Methods
}

\author{
Daniel Perrucci (D) and Hiba Baroud * \\ Department of Civil and Environmental Engineering, Vanderbilt University, Nashville, TN 37235, USA; \\ Daniel.V.Perrucci@vanderbilt.edu \\ * Correspondence: hiba.baroud@vanderbilt.edu
}

Received: 17 November 2020; Accepted: 9 December 2020; Published: 11 December 2020

\begin{abstract}
Temporary housing plays a critical role in disaster response and recovery by providing a temporary home for displaced people before they return to their permanent residence. In recent years, temporary housing has faced three primary dilemmas related to design type, site selection, and cost. Significant contributions have been made in research and in practice to improve temporary housing management. However, gaps still exist in resolving the dilemmas, and a critical review and evaluation of current methods is needed to determine the path forward and identify priorities of future research. This paper presents a comprehensive overview of prior methods developed and applied towards temporary housing management and identifies future pathways for success in temporary housing research and implementation. The literature review reveals that temporary housing requires further research in proactive management, storage, sustainability, and community resilience to effectively enhance post-disaster temporary housing. This study finds that programs such as the Leadership in Energy and Environmental Design (LEED) and the Sheltering and Temporary Essential Power (STEP) program provide methodologies which can benefit temporary housing implementation, designs, and modeling. In addition, circular economy thinking can enable the recyclability of temporary housing to reduce economic and environmental impacts.
\end{abstract}

Keywords: temporary housing; natural disasters; decision-making; design strategies; optimization

\section{Introduction}

The frequency and severity of disasters has amplified since the late 1900s and is only expected to further increase due to climate change, population growth, increasing coastal density, and inadequate disaster preparedness [1-3]. In the event of a disaster, temporary housing is utilized by the displaced residents until they can return to their pre-disaster residence. Of the different types of housing/sheltering phases, temporary housing encompasses the most substantial amount of time and it is the phase which enables resuming pre-disaster life activities [2]. In 2018, disasters led to the prolonged displacement of over 400,000 people globally and required temporary sheltering or housing before resettlement [4].

Post-disaster housing is one of the nation's persistent preparedness challenges, with a single deployment of manufactured housing costing upwards of $\$ 100,000$ [5]. As a result, there is a critical need for sustainable, cost-effective, and efficient temporary housing [1,6]. A lack of prior planning and outdated post-disaster housing strategies has created a complex trade-off between long-term and short-term investment, which impacts the effectiveness of disaster relief $[7,8]$. On one hand, the investments in manufactured temporary housing units during Hurricane Katrina were excessive and short-lived due to the unit's single usage and ultimately, the inconvenient or isolated unit placement which deterred the displaced population from returning for reconstruction and resettlement $[1,9,10]$. 
On the other hand, the long-term investment in pre-existing and reusable housing infrastructure (e.g., rapid maintenance to pre-disaster homes, available rental properties, and hotel rooms) during Hurricane Sandy led to increases in the assistance monies (i.e., higher living costs) provided to individuals for accommodations and ultimately, led to prolonged periods of sheltering [10-12]. Failure to address this trade-off and recent innovation within temporary housing has led to prolonged disaster recovery and over expenditure in individual assistance such as with the Hurricanes Katrina (\$5.7 billion), Sandy (\$1.4 billion), and Harvey (\$1.5 billion) [13-17].

In hindsight, Hurricane Katrina and Hurricane Sandy represent two sides of the post-disaster housing trade-off spectrum (i.e., Hurricane Katrina utilized mainly short-term investment in manufactured units and Hurricane Sandy mainly utilized long-term investment in pre-existing infrastructure). Given the challenge of balancing multiple considerations in temporary housing management (e.g., unit proximity to critical infrastructure and pre-disaster residence, lack of available hotels/rentals, cultural requirements of the region, etc.), all potential temporary housing options must be included in planning considerations and if appropriate, utilized during an event.

To effectively include these planning considerations in future research, this study presents a synthesis of existing unit designs and various models developed for utilization in temporary housing management. We specifically focus on optimization models, multi-criteria decision models, and unit design strategies (qualitative and quantitative) because of their ability to address critical challenges in the planning for temporary including design, site selection, and occupant assignment. The review describes trends in prior studies and proposes directions for future temporary housing research to address gaps in design strategies, sustainability, and community resilience. Specifically, this research shows the importance of proactive temporary housing management, the merit behind modular housing for large-scale storage, the benefit of applying a Leadership in Energy and Environmental Design (LEED)-like evaluation system to temporary housing and the importance of hedging against demand uncertainty with unit pre-stock and a diverse portfolio of temporary housing options.

\section{Background}

\subsection{Defining Temporary Housing}

When a disaster strikes, the impending population displacement requires post-disaster housing accommodations while conducting the necessary reconstruction to their permanent residence. There are three phases for post-disaster accommodations, which are shown in Figure 1 [10,18-22].
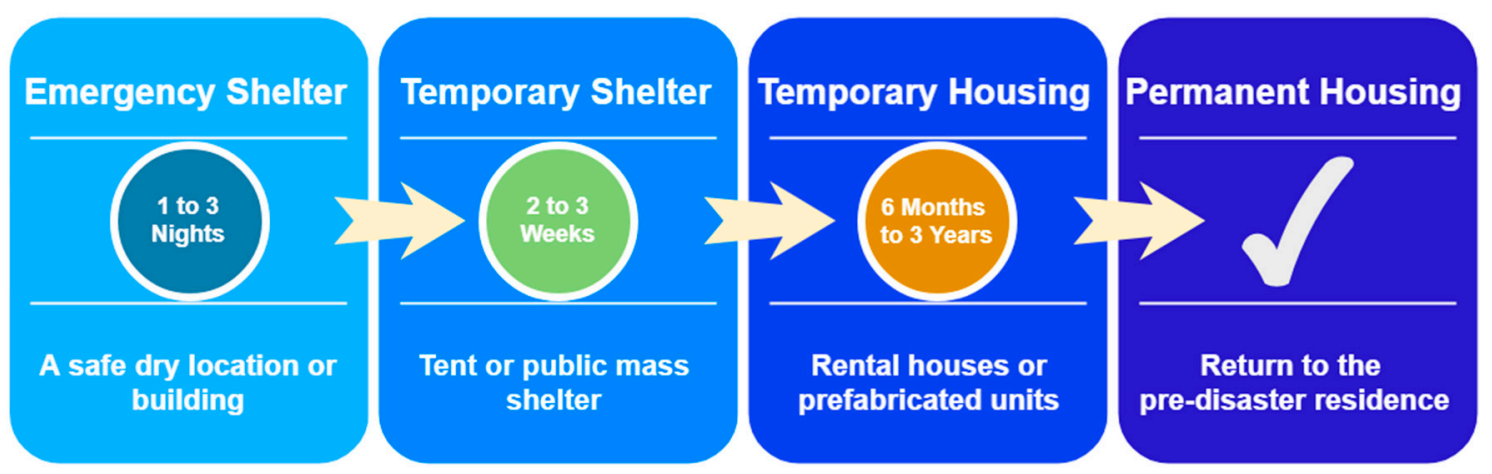

Figure 1. The three phases of post-disaster temporary housing.

The first phase of the post-disaster housing is Emergency Sheltering, where for a series of nights the displaced reside in a safe dry location until they can safely navigate the devastated region. The second phase is known as Temporary Sheltering and is made up of public mass shelters or designated camps. This phase will last 2 to 3 weeks, or until a temporary accommodation is available, and is the transitional period between sheltering and housing. The longest and last segment of post-disaster housing before returning to the pre-disaster residence is the Temporary Housing phase, which can last between 
6 months and 3 years depending on the severity of the devastation. This substantial length of time is spent in a variety of different places, including rental houses, vacant hotel rooms, pre-fabricated kit units, and manufactured temporary housing units [10,18-21]. Once the reconstruction is concluded, the displaced population will return to permanent housing.

A standardized way to define temporary housing stems from section 408 of the Stafford Act and FEMA's empowered Individual Assistance Program, which describes it as transitional housing for the victims whose homes have been destroyed by disasters. The United States standards for temporary housing state that it is only expected to subsist the amount of time between sheltering and permanent housing, which lasts for up to 18 months. The first type of temporary housing initiated is available rental properties, although these can be limited or largely unavailable, as seen during Hurricane Katrina's recovery effort [23]. When rental properties are lacking, mobile and manufactured homes are used. More specifically, mobile homes are utilized when the recovery effort is expected to be short-term, while manufactured homes are commonly used for both short-term (two months or less) and long-term (several months) recovery events $[23,24]$. Contrastingly to FEMA's timeline, academic research suggests temporary housing is expected to last from six months to three years [21].

Beyond these usage timelines, temporary housing units are expected to be easily erected/dismantled, lightweight/transportable, energy-efficient, and "green" with aspects of recyclability and reusability [25]. Temporary housing must allow for normal daily activities (work, schooling, and relaxation) and provide a feeling of security and privacy to the affected [21].

\subsection{Temporary Housing Dilemmas}

The procedures in temporary housing design, deployment, and management influence the occupant's success in recovering [26]. In theory, the supplier of temporary housing seeks to provide the most cost-effective unit that sufficiently increases occupant wellbeing and reduces the displacement duration. As a result, three dilemmas arise.

- Dilemma one is the decision between temporary housing options. A tent is inexpensive, easily constructed, and flexible in placement; however, there are safety (e.g., no rigid walls or locking mechanism) and wellbeing concerns (e.g., sanitation and privacy). In comparison, the costlier manufactured trailer provides increased security and wellbeing with the rigid walls, locking exits, and private living quarters (e.g., a kitchen and bathroom) [26].

- Dilemma two involves the site selection for temporary housing. A temporary housing site is most effective when placed closest to the original housing because it allows the displaced direct access and inclusion during the reconstruction process. However, achieving this proximity can be detrimental to occupants due to ongoing hazards (e.g., fallen trees and disconnected powerlines) $[9,10]$.

- Dilemma three is the cost of temporary housing planning and management. A proactive temporary housing approach requires a significant upfront cost to ensure readily available units at the onset of an event. A delayed order of units during the aftermath of an event minimizes the upfront financial risk but can lead to extreme manufacturing/delivering delays and quality control issues [27,28].

Addressing these dilemmas through research is critical to avoid additional disaster impacts resulting from temporary housing mismanagement. Adverse impacts from these dilemmas have been experienced in previous disasters and they can be grouped into three categories that include expenditure, displacement duration, and wellbeing.

\subsubsection{Expenditure}

The relationship described in dilemma one, between unit cost and satisfaction, is experienced during Indonesia's temporary housing effort after the Tsunami in 2004. The temporary housing consisted of cost-effective tenting inside barracks to provide safety and security. While tents helped reduce costs and the use of barracks mitigated security issues, occupants were still concerned about safety and security [26]. 
In response to lessons learned during Hurricane Katrina, the United States government financed pro-active temporary housing planning. This financing came through the alternative housing programs led by Congress and the Federal Emergency Management Agency (FEMA), allocating a combined $\$ 4$ billion towards temporary housing development and maintenance [29,30]. Two years later, the United States Government Accountability Office determined that FEMA's disaster planning was insufficient and was causing complications (e.g., increased expenditure and delays) when providing temporary housing [31]. These newly funded programs and the confirmation from the United State Government Accountability office illustrate how dilemma three's upfront cost for proactive management and planning is necessary for an efficient implementation.

When Hurricane Sandy landed on the densely populated regions of New York and New Jersey in $2012,1.75$ million people required temporary sheltering; in addition to this, over $\$ 1$ billion worth of individual assistance was provided [11,17]. The increased assistance accounted for the higher cost of living in the impacted region and was the result of utilizing pre-existing infrastructure such as hotels, rental properties, and essential repairs for sheltering in pre-disaster homes as the main methods of transitional and temporary housing, which achieves the desired proximity to the pre-disaster housing but has led to prolonged sheltering and raised assistance expenditure due to an increased cost of living [10-12]. Therefore, the utilized temporary housing methods satisfied dilemma two, at the cost of dilemma one where the chosen temporary housing options led to circumstances which could have been avoided with a diverse portfolio of temporary housing options.

\subsubsection{Displacement Duration}

During Hurricane Katrina, 20,000-30,000 people were displaced and housed in a football stadium nicknamed "The Superdome" for a period of approximately two weeks. However, the amount of people in the shelter quickly deteriorated its conditions and a human health crisis led to wide displacements of citizens around Louisiana and other southern states [32-34]. This broad distribution of temporary housing site locations across states hindered the ability to return to the pre-disaster site and prolonged the recovery overall [9]. The deteriorating conditions led to haste in temporary housing site location decisions, where the consequences of dilemma two disrupted the recovery.

For the most severe situations, FEMA has allotted a time span of 30 to 60 days before temporary housing is provided to communities. This means that a family of four will be displaced in a shelter for up to two months after a disaster and before placement in appropriate temporary housing [35]. During Hurricane Sandy, victims spent almost three months in their damaged homes or in "tent cities" provided by FEMA as artic cold snaps hit the area [12]. A similar situation occurred during Hurricane Harvey where an estimated 100,000 homes were affected by the hurricane and over 30,000 people were still in emergency shelters more than one month afterward [36]. Prior research demonstrates that people who have relocated or are unstably housed for a prolonged period are at increased risk for adverse physical and mental health problems [32,37-39]. These health consequences support significant investment into a proactive temporary housing approach as introduced in dilemma three. Any reductions in transition times between initial displacement, sheltering, and temporary housing would directly reduce the risk of physical or mental health problems.

Another example is the Haitian earthquake in 2011 where more than 300,000 homes were destroyed or damaged, and which caused the migration of nearly 605,000 people in a single province. The temporary housing efforts included distributing tents or tarps for improvised emergency shelters; however, the implementation had logistical problems in demolition, rubble removal, appropriate rehousing of victims, and the acquisition and deliverance of relief supplies. These logistical problems are attributed to a lack of Haitian governance and coordination in humanitarian relief; inadequate assessments of structural integrity, concerns over the historical significance of buildings, and debates on how to remove and dispose of rubble combined to decelerate the appropriation of supplies and the reconstruction of the area. A year later, Haiti had 1.4 million residents still occupying shelters. The temporary housing type, site selection, and neighborhood design increased exposure to other hazards including 
landslides, debris flows, flash floods, and a cholera outbreak. This exposure reiterated the importance of temporary housing organization and unit design (dilemma one and two) due to the impact on recovery prospects [40].

\subsubsection{Health and Social Wellbeing}

Poor temporary housing management can be harmful to human health. For example, when Hurricane Katrina struck the southern coast of the United States in 2005, formaldehyde and 32 other volatile organic chemicals were measured in a selection of temporary housing units. These measured chemical levels in the temporary housing units are from the construction materials and poor airflow $[27,41]$. The presence of these chemicals is a consequence of dilemma three and indicates the importance of quality control through proactive temporary housing planning.

The Tōhoku Earthquake in 2011 led to the creation of a Japanese word "Kodokushi", which describes a suicide inside temporary housing, demonstrating the extreme negative impact of temporary housing mismanagement and neighborhood design with regards to mental health [42,43]. This criticism of temporary housing has been consistent over the past decade for the lack of sufficient unit and location conditions (dilemmas one and two) for displaced families [44,45].

Overall, the success of temporary housing management relies on approaches that consider multiple criteria to address dilemmas and achieve multiple objectives. An optimization of the procedures and designs utilized during temporary housing management will ensure efficiency and the well-being of the recovering population. A review of previous research is needed to evaluate the progress towards solving these three identified dilemmas and recognizing unexplored pathways in the design strategies, decision-making methods, and optimization for successful temporary housing implementation.

\section{Methods}

This study reviewed 106 publications representing five individual publication types, including academic journals, government agency releases, conference publications, news articles, and books. The studies analyzed have been published between the years 1979 and 2020 and cover a wide range of geographical regions including 13 different nations worldwide across North America, South America, Europe, Asia, and Australia.

\subsection{Key Words}

Multiple terms have become synonymous with disaster relief housing. Table 1 provides the description of the three terms that are most commonly used in this research field [46-48].

Table 1. Key Words.

\begin{tabular}{cc}
\hline Terminology & Definition \\
\hline Temporary Housing (TH) & $\begin{array}{c}\text { The placement of manufactured housing units at individual home sites, } \\
\text { existing mobile home parks or newly designed and constructed community } \\
\text { group sites when an event has rendered existing homes uninhabitable [46]. }\end{array}$ \\
\hline Temporary Shelters (TS) & Disaster prevention facilities in densely populated urban areas in \\
developed countries [47].
\end{tabular}

The first stage of the disaster relief process with regards to housing is the emergency shelter. These emergency shelters include any type of public building, including sport venues, universities, and community centers, and are ideally allotted to provide a few days of relief before transitioning to a dedicated disaster relief shelter [21]. This transition leads to the use of temporary shelters, which includes a short stay (few weeks or less) in a mass shelter [19]. These shelter types, emergency shelters and temporary shelters, require the absence of normal life activities and the alteration of known life for the 
affected population [49]. Unlike the previous shelters, temporary housing allows for pre-disaster daily activities to be restarted and are intended to house people for several months or years depending on the severity of the disaster. Once the permanent housing is rebuilt, there is no longer a need for temporary housing unless the unit is updated to provide permanent housing standards [50,51].

\subsection{Meta-Analysis Description}

This section provides a meta-analysis examining the spatio-temporal and thematic distribution of publications.

\subsubsection{Categorization of Articles and Distribution of Geography}

The examined articles have been categorized according to specific themes. These themes are determined by an assessment of each article's outcomes, methodologies, and overarching focus. As seen in Figure 2, the top five categories correspond to social aspects, optimization methods, agency reporting, sustainability, and design.

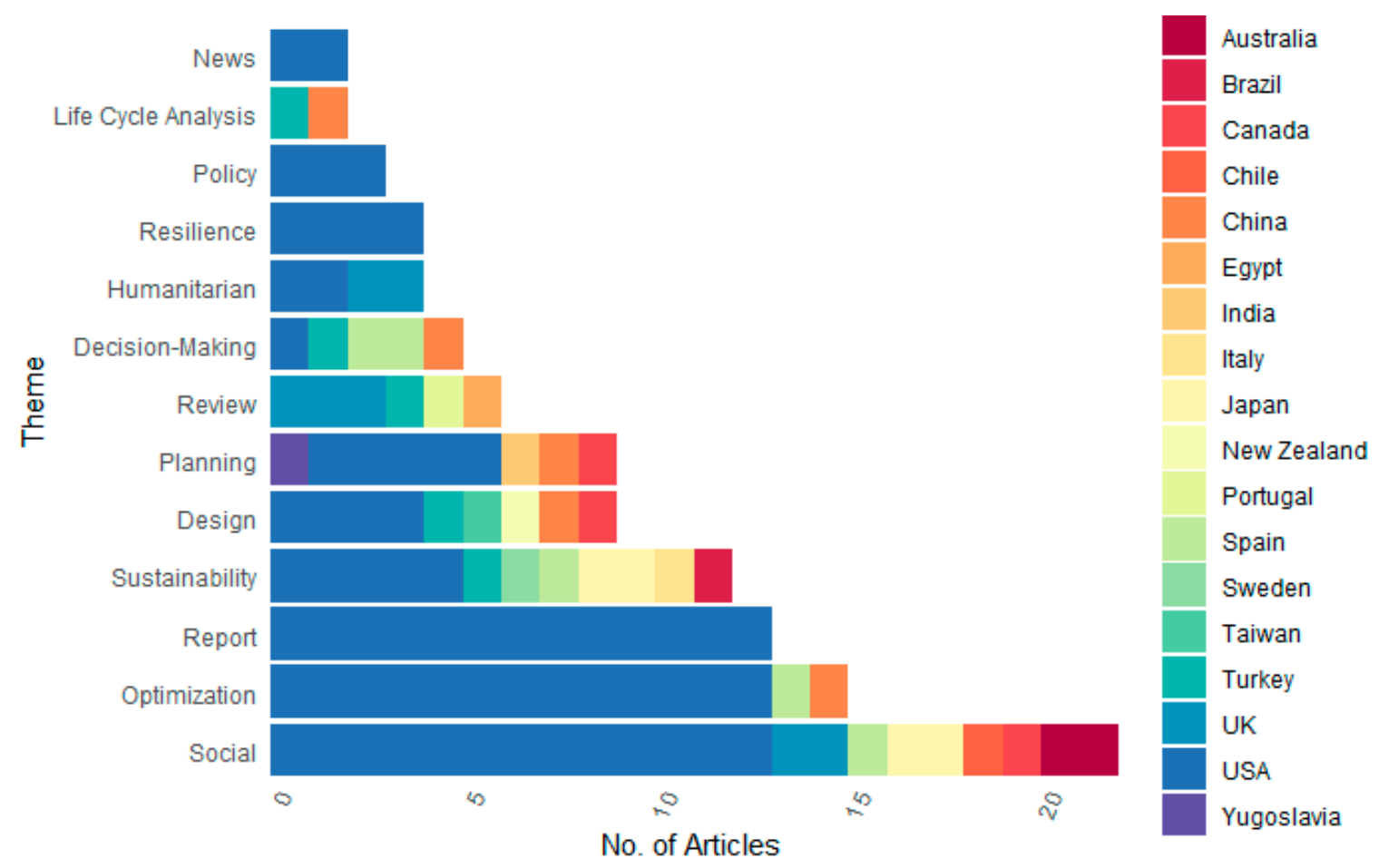

Figure 2. Distribution of the number of articles according to theme categories and countries of first authors.

Additionally, the geographic distribution of first authorship is examined under each theme. Scholars from 14 countries have been contributing to post-disaster housing research. Articles published by authors in the USA constitute the largest portion across all themes except for ones that include life cycle analysis, decision-making, review, and humanitarian aspects. In contrast, agency reporting, news articles, policy, and resilience are themes corresponding to authors in the USA only. Decision making, social, design, and sustainability are global themes with a wide geographic distribution and articles published by authors from across the world.

\subsubsection{Distribution by Publication Year}

Figure 3 is the breakdown of articles by publication year, with the one hundred and seven articles spanning from nearly 1979 to 2020 . Major impact disasters are also indicated on the $x$-axis. It is interesting to note the fluctuations and corresponding nature to the disaster events. Since 2005, 
temporary housing research has seen a cyclical pattern with productivity peaks around a year after a major disaster (e.g., 2007, 2011, 2013, 2018, 2019). This pattern corresponds to a series of international events that reiterated the importance of temporary housing through the mass displacements of people.

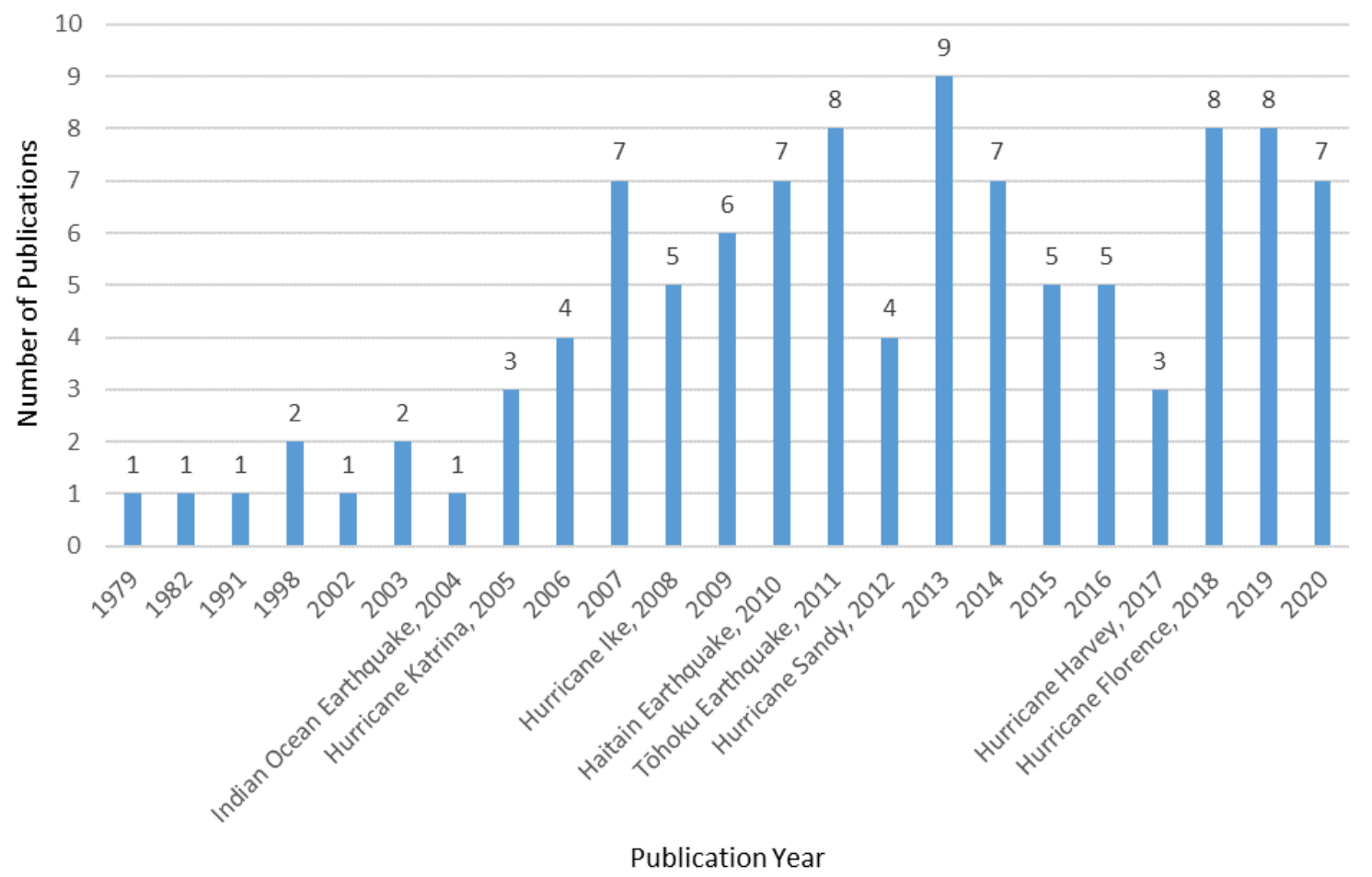

Figure 3. Number of publications by year and corresponding major disasters.

\section{Results}

Prior studies in temporary housing focused on various aspects, such as sustainability, humanitarian aid, public policy, health impacts, and legal issues. The most significant contributions to advancing temporary housing research can be categorized into three areas, (i) decision-making methods, (ii) design strategies, and (iii) optimization models because of their focus on addressing the dilemmas of unit design, site selection, and proactive management.

The studies were categorized according to the methodological approach, which includes optimization, decision-making methods, and design strategies. When applicable, the studies were further classified depending on whether they address the unit (e.g., housing type, occupant needs, and design considerations) or the allocation (e.g., site selection, logistics, and distribution). A summary of these models is provided in Table 2.

Over a span of more than a decade, a series of proposed designs and models have been developed to increase overall effectiveness with regards to various aspects of temporary housing within social, environmental, and economic requirements. Among the early methods considered was a decision-making model developed to integrate temporary housing into prior-planning efforts through the macro-issues (e.g., understanding local conditions, choosing suitable locations, identifying required services), leading to a series of optimization models [18]. 
Table 2. Summary of past temporary housing research.

\begin{tabular}{|c|c|c|c|c|c|c|c|c|}
\hline Date & Type & Focus & Qualitative & Quantitative & Key Methods & Case Study & Hazard Example & Source \\
\hline 2007 & $\begin{array}{c}\text { Decision-Making } \\
\text { Method }\end{array}$ & Allocation & $x$ & & Case Study & Various & Earthquake & Johnson 2007 \\
\hline 2007 & Design Strategies & - & $x$ & & Physical Model & Beci, Turkey & Earthquake & Arslan 2007 \\
\hline 2007-2010 & Optimization & $\begin{array}{l}\text { Unit and } \\
\text { Allocation }\end{array}$ & & $x$ & $\begin{array}{l}\text { Multi-Objective } \\
\text { Weighted } \\
\text { Integer, } \\
\text { Multi-Objective } \\
\text { Genetic } \\
\text { Algorithm }\end{array}$ & General & - & $\begin{array}{c}\text { El-Anwar et al. } \\
2010 \mathrm{a} \\
\text { El-Anwar et al. } \\
2010 \mathrm{~b} \\
\text { El-Anwar and } \\
\text { El-Rayes } 2007 \\
\text { Chen et al. } 2012\end{array}$ \\
\hline 2009 & Design Strategies & - & $x$ & & $\begin{array}{l}\text { Multi-Objective } \\
\text { Design }\end{array}$ & Turkey & Earthquake & $\begin{array}{c}\text { Sener and Altun } \\
2009\end{array}$ \\
\hline 2009-2010 & Optimization & $\begin{array}{l}\text { Unit and } \\
\text { Allocation }\end{array}$ & & $x$ & $\begin{array}{l}\text { Multi-Objective } \\
\text { Genetic } \\
\text { Algorithm }\end{array}$ & General & - & $\begin{array}{c}\text { El-Anwar et al. } \\
2009 \mathrm{~b} \\
\text { Kandil et al. } \\
2010\end{array}$ \\
\hline 2009-2010 & Optimization & Allocation & & $x$ & $\begin{array}{c}\text { Multi-Objective } \\
\text { Genetic } \\
\text { Algorithm }\end{array}$ & General & - & $\begin{array}{c}\text { Chen et al. } 2012 \\
\text { El-Anwar et al. } \\
2009 \text { a } \\
\text { El-Anwar et al. } \\
2010 \\
\text { McLaren et al. } \\
2009 \\
\text { Chen et al. } 2012\end{array}$ \\
\hline 2011 & $\begin{array}{l}\text { Decision-Making } \\
\text { Method }\end{array}$ & Allocation & $x$ & & Case Study & Haití & Earthquake & $\begin{array}{c}\text { Ritchie et al., } \\
2011\end{array}$ \\
\hline 2012 & Optimization & Allocation & & $x$ & $\begin{array}{l}\text { Multi-Objective } \\
\text { Optimization }\end{array}$ & General & - & $\begin{array}{c}\text { El-Anwar et al. } \\
\text { 2012a }\end{array}$ \\
\hline 2012 & Optimization & $\begin{array}{l}\text { Unit and } \\
\text { Allocation }\end{array}$ & & $x$ & $\begin{array}{l}\text { Multi-Objective } \\
\text { Optimization } \\
\text { Multi-Objective }\end{array}$ & General & - & $\begin{array}{l}\text { El-Anwar et al. } \\
2012 b\end{array}$ \\
\hline 2012 & Optimization & $\begin{array}{l}\text { Unit and } \\
\text { Allocation }\end{array}$ & & $x$ & $\begin{array}{l}\text { Optimization, } \\
\text { Cost-Benefit } \\
\text { Analysis }\end{array}$ & General & - & Chen et al. 2012 \\
\hline
\end{tabular}


Table 2. Cont.

\begin{tabular}{|c|c|c|c|c|c|c|c|c|}
\hline Date & Type & Focus & Qualitative & Quantitative & Key Methods & Case Study & Hazard Example & Source \\
\hline 2013 & Design Strategies & - & $X$ & & Review & General & - & Felix et al. 2013 \\
\hline 2014 & Design Strategies & - & $\mathrm{X}$ & & Review & General & - & $\begin{array}{l}\text { Hany Ablunour } \\
2014\end{array}$ \\
\hline 2014 & Design Strategies & - & $x$ & & Physical Model & New York, USA & - & Ford et al. 2014 \\
\hline 2014 & Optimization & Allocation & & $x$ & $\begin{array}{l}\text { Greedy } \\
\text { Heuristics }\end{array}$ & General & Hurricane & $\begin{array}{l}\text { T.R. Rakes et al. } \\
2014\end{array}$ \\
\hline 2014 & Design Strategies & - & $x$ & & $\begin{array}{l}\text { Case Study } \\
\text { Method }\end{array}$ & $\begin{array}{l}\text { USA, Australia, } \\
\text { New Zealand }\end{array}$ & $\begin{array}{c}\text { Earthquake, } \\
\text { Hurricane, Fire }\end{array}$ & $\begin{array}{l}\text { Zhang et al. } \\
2014\end{array}$ \\
\hline 2015 & Design Strategies & - & & $x$ & $\begin{array}{l}\text { Information-Basec } \\
\text { Mechanisms }\end{array}$ & Indonesia & Earthquake & Tsai 2015 \\
\hline 2016 & Optimization & Allocation & & $x$ & $\begin{array}{l}\text { Multi-Objective } \\
\text { Optimization }\end{array}$ & General & - & $\begin{array}{c}\text { El-Anwar et al. } \\
2016\end{array}$ \\
\hline 2016 & $\begin{array}{c}\text { Decision-Making } \\
\text { Method }\end{array}$ & Unit & & $x$ & MIVES Method & Tehran, Iran & Earthquake & $\begin{array}{c}\text { Hosseini et al. } \\
2016\end{array}$ \\
\hline 2017 & Design Strategies & - & $x$ & & Case Study & Various & $\begin{array}{c}\text { Earthquake, } \\
\text { Hurricane, Typhoon }\end{array}$ & Hong 2017 \\
\hline 2018 & Design Strategies & - & $x$ & & Case Study & Japan & Earthquake & Seike et al. 2018 \\
\hline 2018 & Optimization & Allocation & & $x$ & $\begin{array}{l}\text { Newsvendor } \\
\text { Method }\end{array}$ & USA & Hurricane & $\begin{array}{l}\text { Perrucci and } \\
\text { Baroud } 2018\end{array}$ \\
\hline 2018 & Design Strategies & - & $x$ & & Review & Various & $\begin{array}{c}\text { Earthquake, } \\
\text { Hurricane, Refugee }\end{array}$ & $\begin{array}{c}\text { Sagiroglu et al., } \\
2018\end{array}$ \\
\hline 2018 & Design Strategies & - & & $x$ & Social LCA & Chile & Fire & Mora et al., 2018 \\
\hline 2019 & Design Strategies & - & $x$ & & LCA & General & - & $\begin{array}{c}\text { Cascone et al. } \\
2019\end{array}$ \\
\hline 2019 & Design Strategies & - & $x$ & $x$ & Case Study & Japan & Earthquake & $\begin{array}{c}\text { Bris and Bendito } \\
2019\end{array}$ \\
\hline 2020 & $\begin{array}{c}\text { Optimization and } \\
\text { Decision-Making } \\
\text { Method }\end{array}$ & Unit & & $x$ & $\begin{array}{l}\text { MIVES Method, } \\
\text { Backtracking }\end{array}$ & Bam, Iran & Earthquake & $\begin{array}{c}\text { Hosseini et al., } \\
2020\end{array}$ \\
\hline 2020 & Optimization & Allocation & $x$ & $x$ & $\begin{array}{l}\text { AHP, TOPSIS, } \\
\text { Multi-objective } \\
\text { Optimization }\end{array}$ & China & Earthquake & Geng et al., 2020 \\
\hline 2020 & Optimization & Allocation & & $x$ & $\begin{array}{c}\text { ArcGIS } \\
\text { Optimization }\end{array}$ & Macao & Typhoon & Zhao et al. 2020 \\
\hline
\end{tabular}

Note: The background color refers to different study types (e.g., Optimization, Decision-Making Methods, Design Strategies). 
The first temporary housing optimization model focuses on optimizing structural safety, economic impact, and distances from the preferred location; however, that proved to be insufficient and this model is later expanded $[45,52,53]$. The newly expanded model included optimal location options and a method to achieve the desired social, economic, safety, and environmental objectives; although, consideration for occupant preference is not included [45,53-55]. A fourth, more complex model, developed with user preference, resulted in increased computational expense, a combination that hindered the model's feasibility and brought to light a tradeoff between effectiveness and efficiency $[45,52,55,56]$.

In order to address these shortcomings, more advanced methods use a model that considers equivalent distances for allocation and a hybrid housing approach between temporary housing and alternative housing (i.e., hotels, inns, rental properties); while maximizing the socio-economic wellbeing of the occupant. However, the run times are impractical for large-scale implementation [57,58]. As such, a web-based optimization model was developed by Chen et al. (2012) to solve the prolonged runtime and computational expense of past models while minimizing cost and maximizing the social, economic, and physiological benefit of displaced people. The approach heavily depends on a reliable and updated database of temporary housing alternatives [45]. Rakes et al. further expand on occupant-specific needs and assignments to temporary housing units by optimizing the access and proximity to support services [59]. A novel and holistic planning framework is designed to manage expenditure while offering customized housing plans to satisfy these occupant specific social, economic, and psychological needs [60].

Much of these optimization models do not consider pre-stock warehouse quantities and inventory management considerations. Recent models address this gap by including occupant needs with sheltering requirements, capacities, and pre-stock warehouse quantities to determine the best distribution of the displaced people [61]. Other approaches optimize pre-stock inventory as a form of hedging against demand uncertainty, higher costs, and manufacturing delays [10]. One case study of pre-stock inventory consideration optimizes the evacuation distance for displaced citizens with established (i.e., pre-stocked) shelters to promote capacity planning in Macao [62].

In addition to optimizing the management of temporary housing units, a successful implementation also depends on the unit type and design strategies [19]. Five key recommendations for temporary housing unit design include rapid availability, utilization of local resources, compatibility with local living standards (comfort, service, location), planned design life, and the environmentally-friendly removal of units [50].

One approach to achieve these five recommendations is modularity. The modularity in temporary housing design is promoted as a universal unit that adapts to specific occupant needs, raises the quality of life, simplifies storage, and increases deployment and collection speed [63,64]. A novel design from Italy shows how a low-cost modular housing design can improve occupant wellbeing and provide a reduced installation time with improved sustainability [65]. However, a separate study of three prior disasters found that modular designs may not be universally suitable and avoided when social appropriateness does not agree with technical innovation [66]. However, the low cost, short construction period, simplicity of assembly, and sustainable upcycling nature of modular container housing make it a favorable option moving forward [67].

Another aspect of unit design to help lower the environmental impact of temporary housing is sustainability. Sustainable options require the utilization of new resources unlike the reutilization of past units [68]. There are designs promoting the reusability and recyclability of temporary housing, however, governments struggle to achieve the desired sustainable waste management [69]. The key design flaws that discourage the re-use of housing units include material usage (i.e., screws and foundation types) that deter the dismantling of the unit and the inflexibility from the original floor plan. To maximize re-use, designs must account for material usage or apply circular economy methods. If applied correctly, a circular economy transitions previously occupied temporary housing units towards being a material source and a component in the supply chain of new products/units [70]. 
These life cycle costs propagate past unit design and require models to sustainably assess temporary housing site locations, especially to achieve re-utilization [44]. However, it is important to keep occupant wellbeing in mind while adapting temporary housing designs. A social lifecycle analysis (S-LCA) can measure the social impact of unit designs and delivery methodologies, to ensure minimal social impact [71].

\section{Discussion}

The current compilation of academic research has addressed the limitations in temporary housing allocation, providing models and decision methodologies for optimal site location and the satisfaction of occupant specific needs $[45,60]$. Increased global demand for temporary housing has led to significant research advances and innovations in design strategies which satisfy user needs, reduce expenditure, and provide rapid installation $[42,65]$. However, current approaches fail to account for future temporary housing demands, combined novel and existing designs, island relief efforts, social consequences, and the absence in reusing and recycling of temporary housing. Climate-driven severities are feared to increase temporary housing demands, resulting in a gap in current research pertaining to unit storage efficiency and strategies. In the case of island relief, the widely varying requirements and demand as well as the inability to evaluate both novel and existing temporary housing designs produces a gap in pro-active management of temporary housing. Addressing these gaps requires consideration of community resilience in disaster recoveries; however, the social consequences of temporary housing are only starting to be investigated. Finally, from an economic and environmental standpoint, the main concern is the inability to recycle and reuse temporary housing units, which makes accommodation efforts unsustainable due to the short utilization period and raw material consumption. As such, these research gaps are organized into four categories including unit storage strategies, pro-active temporary housing management, community resilience, and sustainability.

This review has identified directions for future research and proposes the following recommendations:

- A decision analysis to simultaneously evaluate existing and novel designs and support pre-stocking of units

- The utilization of prefabricated housing kits and modular units to increase storage capacities

- The creation of a LEED-based rating system to ensure uniform temporary housing sustainability

- An implementation of circular economy methodology to enable recycling and re-use

- An emphasis on social and cultural considerations during the temporary housing process.

The recommended research will advance an exhaustive field of study and prepare to transition and respond to increased climate-driven event severities and temporary housing demand.

\subsection{Pro-Active Temporary Housing Management}

\subsubsection{Modeling and Design Strategies}

Temporary housing management has benefited from the previous decision and optimization models which compiled a variety of methods for site selection and occupant need-based assignment $[45,53,62,72]$. The benefit from design strategies are harder to recognize due to a lacking framework to implement the findings. For instance, these design strategies focus on investigations into modular units, enhancing temporary housing environments, and the creation of novel unit designs. In order to consider innovative designs as plausible options for governments, humanitarians, and other stakeholders looking to supply temporary housing, a formal decision-making process is needed to provide a mechanism for comparing different strategies under different criteria. Additionally, these approaches allow for a collaborative decision-making environment that includes multiple stakeholders from different sectors. Past research is missing a significant piece where novel design 
and previously utilized temporary housing methods are compared simultaneously using social and wellbeing attributes (e.g., privacy, security, lighting) of the units [73].

\subsubsection{Implementation}

When looking at Hurricane Maria's recovery, the United States' territories can benefit from the proactive management of temporary housing. Puerto Rico became a humanitarian crisis as 300,000 homes were damaged, resources became scarce, and a portion of the population shifted to informal reconstruction [74]. To reduce the impact of disasters on these territories and increase resource availability, the United States can pre-stock a larger variety of temporary housing options (i.e., kit supplies and tenting) to ensure availability and ease of intercontinental shipping or pre-stock warehouses on territories for immediate relief. This implementation requires a temporary housing decision-making method to provide the best choice for stakeholders and an updated inventory optimization model to hedge financially against the demand uncertainty.

\subsection{Innovative Storage Designs and Strategies}

\subsubsection{Modeling and Design Strategies}

Depending on the severity of a disaster, displacement can lead to increased demand and a potential inventory management problem with temporary housing units. Studies that attempt to provide an inventory management solution find that temporary housing, especially manufactured units, will require new methodologies for efficient storage [10]. Moving forward, design strategies should transition to prefabricated kit supplies or ease of storage included in considerations when designing a manufactured unit. A partial solution for manufactured unit storage is in the utilization of recycled shipping containers as the base design. The modularity and rigid structure of the containers enable the stacking of units to multiply storage capacities.

\subsubsection{Implementation}

While research includes storage considerations for temporary housing units, the unit design and practical implementation will become more important as demand grows [1,45]. In practice, using shipping container units as temporary housing alternatives results in practical storage options at ports or on ships for an added benefit of mobility to disaster locations [1,73]. Pre-fabricated kits are an alternative option to increase storage capabilities, reduce shipping costs, and still maintain quality of life standards [65].

\subsection{Sustainability}

\subsubsection{Modeling and Design Strategies}

Temporary housing research must consider sustainable solutions. Sustainability aspects have been considered in prior research through modeling and design strategies; however, improvement is needed in two main areas. These areas include an evaluation system for the sustainability of temporary housing units and the implementation of a circular economy for recycling temporary housing at the end of the design life [65,72]. For temporary housing designs, there is a missing evaluation system for sustainability. For instance, novel and established designs can be evaluated using a Leadership in Energy and Environmental Design (LEED) based approach. The LEED approach uses a certification system to evaluate the sustainability of a project based on points obtained with eco-friendly design attributes [75]. A sustainable LEED approach on design, construction, and material composition, increases the upfront cost to provide larger savings over a building's lifetime [76,77]. Once a LEED-based approach is established for temporary housing units, the sustainability of novel unit designs can be uniformly compared. 
Additionally, the lack of re-use in temporary housing is a predicament that research continues to investigate for a number of years $[1,70,78]$. Re-use of a housing unit can present health and maintenance concerns which led response agencies to auction used units [79,80]. Moving forward, re-utilization can be achieved through a circular economy. One definition for circular economy is an economic system that revolves around reducing or alternatively reusing, recycling, and recovering materials for future uses, where rather the recovered waste becomes the new inputs [81]. Using shipping container units again as an example, the metal shell of the unit can be recycled, and the interior design optimized for the recovery of valuable materials. Implementation of this circular economy requires modeling of the ecological exchange of recovered materials and updated design strategies.

\subsubsection{Implementation}

LEED is the most widely adopted sustainable building rating system in the USA and globally, being used in over 167 countries and territories. The feasibility of implementing a LEED-based system would depend on the LEED presence in the specific country. At the end of 2017 certain countries had thousands of LEED projects (e.g., USA, Canada, and China had 30,669 in the USA, 2970 in Canada, and 1211 in China) while other countries have seen a slower implementation of LEED projects (e.g., 275 in Germany, 106 in Korea, and 245 in Turkey). Lack of infrastructure and prior experience with LEED projects are among the main barriers to the implementation of a LEED-based system [76,82]. Given the prior experience with LEED projects and the fact that temporary housing provisions are part of the housing assistance offered by the Federal Emergency Management Agency (FEMA), the implementation of a nationwide LEED-based system in the USA for temporary housing would be feasible. However, the upfront cost or "green premium" is a deterrent for the certification of LEED standards. Therefore, response agencies around the world may be less likely to adopt sustainable attributes [83].

A sustainability ranking system has never been implemented for Temporary Housing and requires a multi-criteria development plan with aspects of LEED's Neighborhood Development. This type of adapted credit system would ensure the desired sustainability through unit design and site development, including credits awarded for reduced resource consumption, indoor air quality, energy efficiency, public spaces, walkable streets, transit facilities, and mixed-use neighborhood centers [84]. With a Temporary Housing LEED accreditation system, the certification of novel and established temporary housing units can contribute to a successful recovery and promote sustainable units and neighborhood resourcefulness $[9,85]$. In doing so, the application of a LEED-based system provides a uniform evaluation process which is sustainable and enables credit considerations for an optimal design that supports re-use. In addition, the system enables key factors that increase community resilience such as an improved quality of life, cultural fulfillment, and greater access to transportation and resources.

A shift from linear to circular consumption of resources is expected as resource scarcity increases. Employing a circular economy for temporary housing units will enable the currently unachievable re-utilization and recycling of valuable resources, while potentially reducing disaster expenditure due to the newfound income. Interestingly, the implementation of a circular economy is historically problematic for certain countries yet almost naturally achieved by others [81]. For effective implementation of circular economy methodologies, the economic benefits must comply with regulatory requirements [86]. In the case of a circular economy revolving around temporary housing units, the newfound income and recycling of previously ineligible materials would satisfy these requirements. In addition, the federal involvement and optimized unit design with pre-defined reusable waste helps address the communication and supply chain trust, which are critical for successfully implementing a circular economy. However, the uncertainty in temporary housing demand can negatively impact the results of a circular economy, where manufacturing would rely on the re-utilization of parts from the deployed temporary housing units [87-89]. In these cases, the only way to ensure productivity is a prior planned secondary supply chain of the required materials. 


\subsection{Community Resilience}

\subsubsection{Modeling and Design Strategies}

Researchers agree that ecological, social, and economic considerations make up three of the main categories in community resilience [90,91]. Existing temporary housing models consider socio-economic factors, which partially address community resilience. However, emergency planning, which includes temporary housing planning, must account for specific social indicators such as regional connectivity, public engagement and trust, inclusion, and awareness [91].

Design strategies benefit from the inclusion of social indicators. For instance, illustrated 3-D unity design descriptions improve public engagement in the planning and construction phases of temporary housing units [92]. Decision-making methods also benefit from the consideration of social indicators. For instance, a model focusing on local government temporary housing decisions would require a decision-making method where the public feature as a key stakeholder with solicited importance weightings and veto capabilities.

In addition, the optimized balancing of supply and demand of temporary housing is important for maximized resilience, especially, considering overages can be used for future events and shortages can lead to extended sheltering with mental health implications [91,93,94]. An allocation and inventory management model is required to hedge against demand uncertainty and reduce adverse social consequences.

\subsubsection{Implementation}

Prior research establishes that a societal connection or social capital is linked to increased community resilience [95-102]. It is important to maintain this societal inclusion with post-disaster management issues [103]. Temporary housing is the first step to providing normalcy and wellbeing for the affected community after a disaster $[19,104]$. The public should be active participants in all temporary housing planning processes due to potential social impact and varying perceptions from differing locations, cultures, and educations [4,105]. A program similar to FEMA's past pilot program known as Sheltering and Temporary Essential Power (STEP) would allow the emergency shelter, temporary shelter, temporary housing, and permanent housing to be combined into one singular entity, enabling homeowner inclusion through the entire process and efficiency of time and resources. While this option improves feasibility, expenditure, and wellbeing during implementation, it has not been fully established in temporary housing research due to a lack of data regarding the success of the recovery activities [106].

\section{Conclusions}

As the world population continues to grow and disasters become more frequent and devastating, temporary housing will increasingly be a critical aspect of disaster response and recovery $[1,2]$. The increased frequency and the enlarged number of displaced peoples will require a series of novel designs, decision-making methodologies, and optimization models for temporary housing to ensure the safety, wellbeing, and ability to recover. Overall, this review of the literature reveals that the previous designs and models focusing on temporary housing have made necessary steps; however, there is a major deficit to be filled by novel unit decision evaluation, maximized storage capacities, sustainable unit designs, and community resilience indicators.

This current compilation of temporary housing designs, decision methodologies, and optimization models require further expansion to solve future challenges of temporary housing dilemmas.

Author Contributions: Conceptualization, D.P. and H.B.; methodology, D.P.; formal analysis, D.P.; resources, D.P. and H.B.; writing-original draft preparation, D.P.; writing—review and editing, H.B.; visualization, D.P. and H.B.; supervision, H.B.; project administration, H.B.; funding acquisition, H.B. All authors have read and agreed to the published version of the manuscript.

Funding: This research received was funded by Vanderbilt University. 
Conflicts of Interest: The authors declare no conflict of interest.

\section{References}

1. Perrucci, D.V.; Vazquez, B.A.; Aktas, C.B. Sustainable Temporary Housing: Global Trends and Outlook. Procedia Eng. 2016, 145, 327-332. [CrossRef]

2. Opricovic, S.; Tzeng, G.H. Multicriteria planning of post-earthquake sustainable reconstruction. Comput. Civ. Infrastruct. Eng. 2002, 17, 211-220. [CrossRef]

3. Atmaca, N. Life-cycle assessment of post-disaster temporary housing. Build. Res. Inf. 2017, 45, 524-538. [CrossRef]

4. Venable, C.; Javernick-Will, A.; Liel, A.B. Perceptions of Post-Disaster Housing Safety in Future Typhoons and Earthquakes. Sustainability 2020, 12, 3837. [CrossRef]

5. Windle, M.; Quraishi, S.; Goentzel, J. Disaster Housing Construction Challenges Exploring the Role of Factory-Built Housing; MIT Humanitarian Supply Chain Lab, MIT Center for Transportation \& Logistics.: Cambridge, MA, USA, 2019; Available online: https://dspace.mit.edu/handle/1721.1/122651.6 (accessed on 9 December 2020).

6. Schmeltz, M.T.; González, S.K.; Fuentes, L.; Kwan, A.; Ortega-williams, A.; Cowan, L.P. Lessons from Hurricane Sandy: A Community Response in Brooklyn, New York. J. Urban Health 2013, 90. [CrossRef]

7. Hidayat, B.; Egbu, C. A Literature Review of the Role of Project Management in Post-Disaster Reconstruction. In Proceedings of the 26th Annual ARCOM Conference, Leeds, UK, 6-8 September 2010; pp. 1269-1278.

8. Vitoriano, B.; Ortuño, M.T.; Tirado, G.; Montero, J. A multi-criteria optimization model for humanitarian aid distribution. J. Glob. Optim. 2011, 51, 189-208. [CrossRef]

9. Campanella, T.J. Urban Resilience and the Recovery of New Orleans. Am. Plan. Assoc. 2006, 72, $141-147$. [CrossRef]

10. Perrucci, D.V.; Baroud, H. Improving Community Resilience through Post-Disaster Temporary Housing Optimization. In Proceedings of the Probabilistic Safety Assessment and Management PSAM 14, Los Angeles, CA, USA, 16-21 September 2018.

11. Hurricane Sandy FEMA After-Action Report; FEMA: Washington, DC, USA, 2013.

12. Bucci, S.P.; Inserra, D.; Lesser, J.; Mayer, M.A.; Slattery, B.; Spencer, J.; Tubb, K. After Hurricane Sandy: Time to Learn and Implement the Lessons in Preparedness, Response, and Resilience from the heritage foundation emergency preparedness working group. Herit. Found. 2013, 144. Available online: https://www.heritage.org/homelandsecurity/report/after-hurricane-sandy-time-learn-and-implement-the-lessons-preparedness (accessed on 9 December 2020).

13. Rebuilding Stronger and Faster after Natural Disasters in the Aftermath of Hurricanes; U.S. Department of Housing and Urban Development's Office of PD\&R Edge: Washington, DC, USA, 2019.

14. Mickelson, S.; Patton, N.; Gordon, A.; Rammler, D. Fixing America's Broken Disaster Housing Recovery System; NLIHC: Washington, DC, USA, 2019.

15. FEMA. Hurricane Harvey 6 Months Later Texas Hurricane Harvey Recovery Guide; FEMA: Washington, DC, USA, 2018; Volume 3362.

16. Womack, M. Louisiana-Hurricanes Katrina \& Rita; FEMA: Washington, DC, USA, 2015.

17. Fugate, C. One Year Later: Examining the Ongoing Recovery from Hurricane Sandy; U.S. Department of Homeland Security: Washington, DC, USA, 2013; pp. 1-15.

18. Johnson, C. Strategic planning for post-disaster temporary housing. Disasters 2007, 31, 435-458. [CrossRef]

19. Félix, D.; Branco, J.M.; Feio, A. Temporary housing after disasters: A state of the art survey. Habitat Int. 2013, 40, 136-141. [CrossRef]

20. Quarantelli, E.L. Disaster planning for transportation accidents involving hazardous materials. J. Hazard. Mater. 1991. [CrossRef]

21. Bashawri, A.; Garrity, S.; Moodley, K. An Overview of the Design of Disaster Relief Shelters. Procedia Econ. Financ. 2014, 18, 924-931. [CrossRef]

22. Kreimer, A. Emergency, temporary and permanent housing after disasters in developing countries. Ekistics 1979, 279, 361-365.

23. FEMA. Environmental Assessment Alternative Housing Pilot Program Jackson Barracks Site; U.S. Department of Homeland Security: New Orleans, LA, USA, 2008. 
24. Hurricane Sandy Rebuilding Strategy; U.S. Department of Housing and Urban Development: Washington, DC, USA, 2013.

25. Song, Y.; Mithraratne, N.; Zhang, H. Life-time performance of post-disaster temporary housing: A case study in Nanjing. Energy Build. 2016, 128, 394-404. [CrossRef]

26. Biswas, A. Exploring Indian post-disaster temporary housing strategy through a comparative review. Int. J. Disaster Resil. Built Environ. 2019, 10, 14-35. [CrossRef]

27. Maddalena, R.; Russell, M.; Sullivan, D.P.; Apte, M.G. Formaldehyde and Other Volatile Organic Chemical Emissions in Four FEMA Temporary Housing Units. Enviromental Sci. Technol. 2009, 43, 5626-5632. [CrossRef]

28. Johnson, C. Impacts of prefabricated temporary housing after disasters: 1999 earthquakes in Turkey. Habitat Int. 2007, 31, 36-52. [CrossRef]

29. El-Anwar, O.; El-Rayes, K.; Elnashai, A. Maximizing Temporary Housing Safety after Natural Disasters. J. Infrastruct. Syst. 2010, 16, 138. [CrossRef]

30. FEMA Disaster Assistance: A Guide to Recovery Programs; FEMA: Washington, DC, USA, 2005; Volume 229.

31. Pierre, J.K.; Stephenson, G.S.; Pierre, J.K.; Stephenson, G.S. After Katrina: A Critical Look at FEMA ' s Failure to Provide Housing for Victims of Natural Disasters Provide Housing for Victims of Natural Disasters. La. Law Rev. 2008, 68, 443-495.

32. Nigg, J.M.; Barnshaw, J.; Torres, M.R. Hurricane Katrina and the Flooding of New Orleans: Emergent Issues in Sheltering and Temporary Housing. Ann. Am. Acad. Pol. Soc. Sci. 2006, 604, 113-128. [CrossRef]

33. Waugh, W.L. The Political Costs of Failure in the Katrina and Rita Disasters. Ann. Am. Acad. Pol. Soc. Sci. 2006, 604, 10-25. [CrossRef]

34. Masozera, M.; Bailey, M.; Kerchner, C. Distribution of impacts of natural disasters across income groups: A case study of New Orleans. Ecol. Econ. 2006, 63, 299-306. [CrossRef]

35. Dombi, J. Temporary Housing — Permanent Impressions. Military Eng. 2011, 104, 69-70.

36. Fessler, P. At Least 100,000 Homes Were Affected by Harvey. Moving Back in Won't be Easy; NPR: Washington, DC, USA, 2017.

37. Fussell, E.; Lowe, S.R. Social Science \& Medicine The impact of housing displacement on the mental health of low-income parents after Hurricane Katrina. Soc. Sci. Med. 2014, 113, 137-144. [CrossRef]

38. Merdjanoff, A.A. There's no place like home: Examining the emotional consequences of Hurricane Katrina on the displaced residents of New Orleans. Soc. Sci. Res. 2013, 42, 1222-1235. [CrossRef]

39. Paxson, C.; Fussell, E.; Rhodes, J.; Waters, M. Five years later: Recovery from post traumatic stress and psychological distress among low-income mothers affected by Hurricane Katrina. Soc. Sci. Med. 2011, 74, 150-157. [CrossRef]

40. Ritchie, L.A.; Tierney, K. Temporary housing planning and early implementation in the 12 January 2010 haiti earthquake. Earthq. Spectra 2011, 27. [CrossRef]

41. Levine, J.N.; Esnard, A.-M.; Sapat, A. Population Displacement and Housing Dilemmas Due to Catastrophic Disasters. J. Plan. Lit. 2007, 22, 3-15. [CrossRef]

42. Bris, P.; Bendito, F. Impact of Japanese post-disaster temporary housing areas' (THAs) design on mental and social health. Int. J. Environ. Res. Public Health 2019, 16, 4757. [CrossRef]

43. Koyama, S.; Aida, J.; Kawachi, I.; Kondo, N.; Subramanian, S.V.; Ito, K.; Kobashi, G.; Masuno, K.; Kondo, K.; Osaka, K. Social Support Improves Mental Health among the Victims Relocated to Temporary Housing following the Great East Japan Earthquake and Tsunami. Tohoku J. Exp. Med. 2014, 234, 241-247. [CrossRef]

44. Amin Hosseini, S.M.; De La Fuente, A.; Pons, O. Multi-criteria decision-making method for assessing the sustainability of post-disaster temporary housing units technologies: A case study in Bam, 2003. Sustain. Cities Soc. 2016, 20, 38-51. [CrossRef]

45. Chen, L.; El-anwar, O.; Heim, J.A.; Chen, L. A Web-based System for Optimizing Post Disaster Temporary Housing Allocation. Ph.D. Thesis, University of Washington, Seattle, WA, USA, 2012.

46. Temporary Housing and Critical Public Facilities Information Paper; US Army Corps of Engineers: Washington, DC, USA; pp. 1-2.

47. Liu, Q.; Ruan, X.; Shi, P. Selection of emergency shelter sites for seismic disasters in mountainous regions: Lessons from the 2008 Wenchuan Ms 8.0 Earthquake, China. J. Asian Earth Sci. 2011, 40, 926-934. [CrossRef]

48. Kar, B.; Hodgson, M.E. A GIS-based model to determine site suitability of emergency evacuation shelters. Trans. GIS 2008, 12, 227-248. [CrossRef] 
49. Quarantelli, E.L. General and particular observations on sheltering and housing in American disasters. Disasters 1982, 6, 277-281. [CrossRef]

50. Hany Abulnour, A. The post-disaster temporary dwelling: Fundamentals of provision, design and construction. HBRC J. 2013, 10, 10-24. [CrossRef]

51. Mcintosh, J. The Implications of Post Disaster Recovery for Affordable Housing. Intech 2013. [CrossRef]

52. El-Anwar, O.; El-Rayes, K.; Elnashai, A. Optimizing Large-Scale Temporary Housing Arrangements after Natural Disasters. J. Comput. Civ. Eng. 2009, 23, 110-118. [CrossRef]

53. El-Anwar, O.; El-Rayes, K.; Elnashai, A. An automated system for optimizing post-disaster temporary housing allocation. Autom. Constr. 2009, 18, 983-993. [CrossRef]

54. El-Anwar, O.; El-Rayes, K. Post-Disaster Optimization of Temporary Housing Efforts. In Proceedings of the ASCE Construction Research Congress, Grand Bahama Island, Bahamas, 6-8 May 2007.

55. El-anwar, O.; Kandil, A.; El-rayes, K.; El-anwar, O. Optimization Research: Enhancing the Robustness of Large-Scale Multiobjective Optimization in Construction. Constr. Eng. Manag. 2010. [CrossRef]

56. El-Anwar, O.; El-Rayes, K.; Elnashai, A.S. Maximizing the Sustainability of Integrated Housing Recovery Efforts. J. Constr. Eng. Manag. 2010, 136, 794-802. [CrossRef]

57. El-Anwar, O. Advancing Optimization of Hybrid Housing Development Plans Following Disasters: Achieving Computational Robustness, Effectiveness, and Efficiency. J. Comput. Civ. Eng. 2012, 27, 358-369. [CrossRef]

58. El-Anwar, O.; Chen, L. Computing a Displacement Distance Equivalent to Optimize Plans for Postdisaster Temporary Housing Projects. ASCE 2012, 139, 174-184. [CrossRef]

59. Rakes, T.R.; Deane, J.K.; Rees, L.P.; Fetter, G.M. A decision support system for post-disaster interim housing. Decis. Support Syst. 2014, 66, 160-169. [CrossRef]

60. El-Anwar, O.; Chen, L. Automated Community-Based Housing Response: Offering Temporary Housing Solutions Tailored to Displaced Populations Needs. J. Comput. Civ. Eng. 2016. [CrossRef]

61. Geng, S.; Hou, H.; Zhang, S. Multi-Criteria Location Model of Emergency Shelters in Humanitarian Logistics. Sustainability 2020, 12, 1759. [CrossRef]

62. Zhao, X.; Du, P.; Chen, J.; Yu, D.; Xu, W.; Lou, S.; Yuan, H.; Ip, K.P. A typhoon shelter selection and evacuee allocation model: A case study of macao (SAR), China. Sustainability 2020, 12, 3308. [CrossRef]

63. Sener, S.M.; Altun, M.C. Design of a post disaster temporary shelter unit. A|Z ITU J. Fac. Archit. 2009, 6, 58-74. [CrossRef]

64. Ford, G.; Ahn, Y.H.; Choi, D.M. Modular Building for Urban Disaster Housing: Case Study of Urban Post-Disaster Housing Prototype in New York. Fire Sci. Eng. 2014, 28, 82-89. [CrossRef]

65. Cascone, S.M.; Caruso, C.; Russo, G.; Cascone, S.M.; Russo, G. Sustainability and innovation in constructions intended for emergency housing. Technol. Eng. Mater. Archit. 2019, 5. [CrossRef]

66. Zhang, G.; Setunge, S.; van Elmpt, S. Using Shipping Containers to Provide Temporary Housing in Post-disaster Recovery: Social Case Studies. Procedia Econ. Financ. 2014, 18, 618-625. [CrossRef]

67. Hong, Y. A study on the condition of temporary housing following disasters: Focus on container housing. Front. Archit. Res. 2017, 6, 374-383. [CrossRef]

68. Sagiroglu, M. Learning from the Experiences of Using Different Types of Temporary Housing Systems. In Proceedings of the 42nd IAHS World Congress, Naples, Italy, 10-13 April 2018.

69. Arslan, H. Re-design, re-use and recycle of temporary houses. Build. Environ. 2007, 42, 400-406. [CrossRef]

70. Seike, T.; Kim, Y.; Hosaka, Y.; Ida, S.; Masuda, T. Intraregional reuse of emergency temporary housing in Japan. Sustain. Cities Soc. 2018, 42, 650-662. [CrossRef]

71. Mora, M.; Akinci, B. Measuring the Social Impact of Innovation in the Fabrication and Delivery of Post-Disaster Temporary Housing-2017 Fire in Chile Case Study. In Proceedings of the Proceeding of Construction Research Congress, New Orleans, LA, USA, 2-4 April 2018; pp. 429-438.

72. Hosseini, S.M.A.; de la Fuente, A.; Pons, O. Multicriteria Decision-Making Method for Sustainable Site Location of Post-Disaster Temporary Housing in Urban Areas. J. Constr. Eng. Manag. 2016, 142, 04016036. [CrossRef]

73. Akdede, N. Evaluation of Temporary Housing Units with Multi-Criteria Decision Making Methods; Middle East Technical University: Ankara, Turkey, 2018. 
74. Talbot, J.; Poleacovschi, C.; Hamideh, S.; Santos-Rivera, C. Informality in Postdisaster Reconstruction: The Role of Social Capital in Reconstruction Management in Post-Hurricane Maria Puerto Rico. J. Manag. Eng. 2020, 36, 04020074. [CrossRef]

75. Castro-lacouture, D.; Sefair, J.A.; Flo, L. Optimization model for the selection of materials using a LEED-based green building rating system in Colombia. Build. Environ. 2009, 44, 1162-1170. [CrossRef]

76. Azhar, S.; Carlton, W.A.; Olsen, D.; Ahmad, I. Automation in Construction Building information modeling for sustainable design and LEED ${ }^{\circledR}$ rating analysis. Autom. Constr. 2011, 20, 217-224. [CrossRef]

77. Heerwagen, J.H.; Heerwagen, J.H. Investing in People: The Social Benefits of Sustainable Design; J.H. Heerwagen \& Associates, Inc.: Seattle, WA, USA, 2006; pp. 1-17.

78. Hosseini, S.M.A.; Yazdani, R.; De, A. Multi-objective interior design optimization method based on sustainability concepts for post-disaster temporary housing units. Build. Environ. 2020, 173, 106742. [CrossRef]

79. Government Auctions and Sales Government Sales of Seized and Surplus Property. Available online: https://www.usa.gov/auctions-and-sales\#item-36772 (accessed on 16 July 2020).

80. McCarthy, F.X. FEMA Disaster Housing: From Sheltering to Permanent Housing; Congressional Research Service: Washington, DC, USA, 2010; pp. 49-78.

81. de Abreu, M.C.S.; Ceglia, D. On the implementation of a circular economy: The role of institutional capacity-building through industrial symbiosis. Resour. Conserv. Recycl. 2018, 138, 99-109. [CrossRef]

82. Stanley, S.U.S. Green Building Council Releases Annual Top 10 Countries and Regions for LEED; USGBC: Washington, DC, USA, 2018.

83. Mosier, R.; Gransberg, D.D. A Framework to Reconcile Green Goals with Budget Reality. ISRN Constr. Eng. 2013, 2013, 1-10. [CrossRef]

84. Szibbo, N.A. Assessing Neighborhood Livability: Evidence from LEED ${ }^{\circledR}$ for Neighborhood Development and New Urbanist Communities. J. Urban Res. 2015. [CrossRef]

85. Chamlee-wright, E.; Storr, V.H. Social capital as collective narratives and post-disaster community recovery. Sociol. Rev. 2011, 2. [CrossRef]

86. Bain, A.; Shenoy, M.; Ashton, W.; Chertow, M. Industrial symbiosis and waste recovery in an Indian industrial area. Resour. Conserv. Recycl. 2010, 54, 1278-1287. [CrossRef]

87. Gibbs, D. Trust and Networking in Inter-firm relations: the Case of Eco-Industrial Development. Local Econ. 2003, 18, 222-236. [CrossRef]

88. Veleva, V.; Todorova, S.; Lowitt, P.; Angus, N.; Neely, D. Understanding and addressing business needs and sustainability challenges: Lessons from Devens eco-industrial park. J. Clean. Prod. 2015, 87, 375-384. [CrossRef]

89. Mirata, M.; Emtairah, T. Industrial symbiosis networks and the contribution to environmental innovation: The case of the Landskrona industrial symbiosis programme. J. Clean. Prod. 2005, 13, 993-1002. [CrossRef]

90. Cutter, S.; Barnes, L.; Berry, M.; Burton, C.; Evans, E.; Tate, E.; Webb, J. A place-based model for understanding community resilience to natural disasters. Glob. Environ. Chang. 2008, 18, 598-606. [CrossRef]

91. Gillespie-Marthaler, L.; Nelson, K.; Baroud, H.; Abkowitz, M. Selecting Indicators for Assessing Community Sustainable Resilience. Risk Anal. 2019, 39, 2479-2498. [CrossRef]

92. Tsai, M.K. Designing Postdisaster Temporary Housing Facilities: Case Study in Indonesia. Nat. Hazards Rev. 2015, 16, 1-9. [CrossRef]

93. Casey, B. Casey Urges FEMA to Consider Giving Unused Trailers from Irene and Lee to States Impacted by Sandy; U.S. Senator for Pennsylvania: Washington, DC, USA, 2012.

94. Kessler, R.C.; Galea, S.; Gruber, M.J.; Sampson, N.A.; Ursano, R.J.; Wessely, S. Trends in mental illness and suicidality after Hurricane Katrina. Mol. Psychiatry 2008, 13, 374-384. [CrossRef]

95. Murphy, B.L. Locating social capital in resilient community-level emergency management. Nat. Hazards 2007. [CrossRef]

96. Bolin, R.; Stanford, L. The Northridge Earthquake: Community-based Approaches to Unmet Recovery Needs. Disasters 1998, 22, 21-38. [CrossRef] [PubMed]

97. Chamlee-Wright, E. The Cultural and Political Economy of Recovery: Social Learning in a Post-Disaster Environment; Routledge: New York, NY, USA, 2010; ISBN 0203855922.

98. Chamlee-Wright, E.; Storr, V.H. Club goods and post-disaster community return. Ration. Soc. 2009. [CrossRef] 
99. Paton, D. Preparing for natural hazards: The role of community trust. Disaster Prev. Manag. An Int. J. 2007. [CrossRef]

100. Pelling, M. Participation, social capital and vulnerability to urban flooding. Int. Dev. 1998. [CrossRef]

101. Pelling, M.; High, C. Understanding adaptation: What can social capital offer assessments of adaptive capacity? Glob. Environ. Chang. 2005, 15, 308-319. [CrossRef]

102. Shaw, R.; Goda, K. From disaster to sustainable civil society: the Kobe experience. Disasters 2004, $28,16-40$. [CrossRef]

103. Ueda, Y.; Shaw, R. Managing and bridging communities in temporary housing: case of the Great East Japan Earthquake and Tsunami in Kesennuma City, Japan. Nat. Hazards 2015, 80, 567-587. [CrossRef]

104. Barakat, S. Housing reconstruction after conflict and disaster. Humanit. Policy Group Netw. Pap. 2003, 1-46.

105. Faure, J.C.; Faust, K.M.; Kaminsky, J. Stakeholder Legitimization of the Provision of Emergency Centralized Accommodations to Displaced Persons. Sustainability 2020, 12, 284. [CrossRef]

106. Harriss, L.; Parrack, C.; Jordan, Z. Building safety in humanitarian programmes that support post-disaster shelter self-recovery: an evidence review. Disasters 2020, 44, 307-335. [CrossRef] [PubMed]

Publisher's Note: MDPI stays neutral with regard to jurisdictional claims in published maps and institutional affiliations.

(C) 2020 by the authors. Licensee MDPI, Basel, Switzerland. This article is an open access article distributed under the terms and conditions of the Creative Commons Attribution (CC BY) license (http://creativecommons.org/licenses/by/4.0/). 